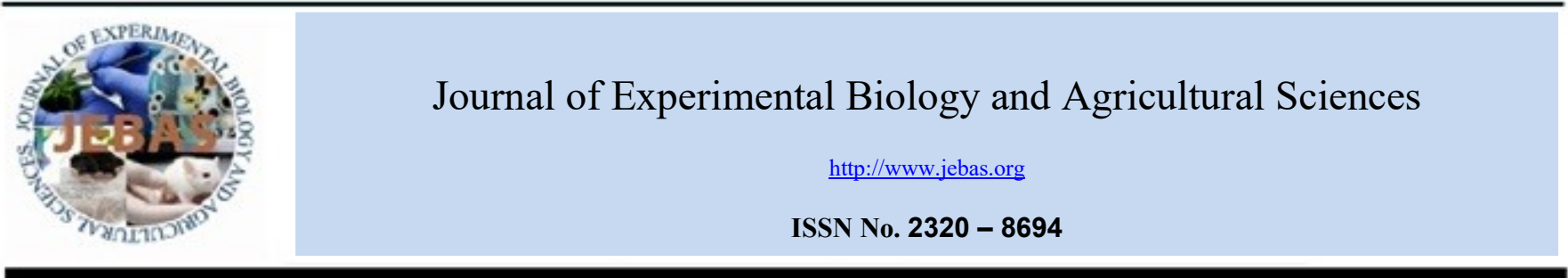

\title{
EXTRACTION AND CHARACTERIZATION OF NATURAL DYE FROM Thymus vulgaris L AND ITS USE IN DYEING CELLULOSIC SUBSTRATE
}

\author{
ALOUANI Imane*, DRAOUI Mustapha, TOURE Hamadoun Abba, BOUATIA Mustapha \\ Laboratory of Analytical Chemistry; Faculty of Medicine and Pharmacy; Mohammed V University in Rabat, Morocco \\ Received - April 24, 2020; Revision - May 28, 2020; Accepted - August 09, 2020 \\ Available Online - August 25, 2020 \\ DOI: http://dx.doi.org/10.18006/2020.8(4).489.499
}

KEYWORDS
Natural dye
Thymus vulgaris
Plant pigments
Extraction
Mordant
Cellulosic substrate

\begin{abstract}
Thymus vulgaris is a rich source of polyphenols such as flavonoids and anthocyanins, which can be used as a natural dye. This study aimed to evaluate the color spectrum of $T$. vulgaris by combining different parameters such as extraction methods, pre-treatment, mordanting with additives, and metals. The natural dye was isolated from the hot water extract of $T$. vulgaris aerial part powder and characterized by TLC Chromatography. The results of the study revealed that $T$. vulgaris could be qualified as natural dyes and give several colors such as yellow without mordant, several green shades with ferrous sulfate, and from green to deep red with copper sulfate. The colors were stable for a minimum of two months with $\mathrm{DE}<1$. The color fastness like the washing and friction resistance is directly related to the specific type of used mordant and rate of additives. In addition to this, the use of the metal-mordants coupled with the additives forms "lacquers" and brings a low fastness. For copper sulfate, the fastness remains good. A wide spectrum of colors has been obtained by modifying the amount of mordant and/ or metal mordant ranging from yellow to green to pink to brick red. These study results extended the application of $T$. vulgaris as a natural dye like for a cellulosic substrate.
\end{abstract}

\section{Abbreviations:}

ONSSA: National Office for Sanitary Safety of Food Products, Sodium sulfate $\left(\mathrm{Na}_{2} \mathrm{SO}_{4}\right)$; Sodium Carbonate $\left(\mathrm{Na}_{2} \mathrm{CO}_{3}\right)$; Ferrous sulfate $\left(\mathrm{FeSO}_{4}, 7 \mathrm{H}_{2} \mathrm{O}\right)$; Copper (II) sulfate $\left(\mathrm{CuSO}_{4}, 5 \mathrm{H}_{2} \mathrm{O}\right)$; Oxalic acid $\left(\mathrm{C}_{2} \mathrm{H}_{2} \mathrm{O}_{4}, 2 \mathrm{H}_{2} \mathrm{O}\right)$.
* Corresponding author

E-mail: imane.alouani@itech.fr (Imane ALOUANI)

Peer review under responsibility of Journal of Experimental Biology and Agricultural Sciences.

Production and Hosting by Horizon Publisher India [HPI] (http://www.horizonpublisherindia.in/).

All rights reserved.
All the articles published by Journal of Experimental Biology and Agricultural Sciences are licensed under a Creative Commons Attribution-NonCommercial 4.0 International License Based on a work at www.jebas.org.

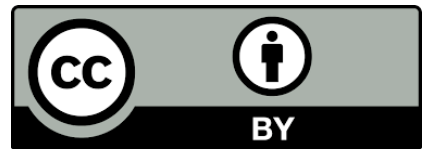




\section{Introduction}

Plant based natural products have a long history to use as natural dyes, these dyes are widely used for coloring fibers such as cotton, silk, and wool. Indeed, the earliest written document of using natural dyes is from China and it was 2600 BC. Further, documentary shreds of evidence from Mexico and Peru also suggested the use of Cochineal as a dyestuff for textiles and paints industries almost 3000 years ago is also available (Křížová, 2015). The fabrics of ancient Egypt are the remarkable testimony of the coloring power of plant based natural dyes (Vankar, 2000).

Natural dyes are derived from various natural sources such as plants, animals and minerals. Among these plants have been the most commonly used sources and almost all plant parts serve as sources of natural dye. Therefore, a dye plant is a plant capable of biosynthetically producing a substance that filters photons, absorb specific wavelength light, and reflects the rest of the spectrum, energy, and variable wavelength (Delgado-Vargas et al., 2000; Ben Mansour \& Latrach Tlemcani, 2009; Garcia et al., 2014). The use of natural dyes started to decline after the invention of the first synthetic dyes in 1856 (Viel, 2005; Shahid et al., 2013).

Brighter color, easy availability, and consistency in shades, like characteristics of synthetic dyes enhance the speed of natural dyes replacement and currently, it has only $1 \%$ share in textile sectors (Samanta \& Agarwal, 2009; Sivakumar et al., 2011; Rajesh et al., 2014). Last few decades, people's concern regarding the drawbacks of synthetic dyes increased and this provoked environmentally conscious researchers to explore new eco-friendly dyes. These natural dyes are not only eco-friendly but also non-allergic, nontoxic, renewable, biodegradable, and skin-friendly, that's why now in these days natural dyes again get more attention in textiles, food and cosmetic industries (Samant \& Gaikwad, 2020).

More than 450 dyeing plants are already explored for their coloring behavior; but Rubia tinctorum (source of Red color), and Indigofera tinctoria (source of blue shade) are the most commonly used ones (Cardon, 2014; Rajesh et al., 2014). Alouani et al. (2016) prepared an inventory of Moroccan natural dyeing flora and listed 118 species, among these, $T$. vulgaris identified as a potential source of dye.

Thymus vulgaris belongs to the Lamiaceae family, is a well known aromatic plant which significantly used for its leaves and flowers essential oil, foodstuff, pharmaceutical, and cosmetic product (Rababah et al., 2010). The essential oil isolated (0.5 to $2 \%$ ) from various plant parts, is well recognized for its antiseptic and antispasmodic activities (Bellakhdar, 2006; Richaud, 2014). The active ingredients of the essential oil are thymol, carvacrol, and bornéol (Bellakhdar, 2006). A wide variety of secondary metabolites such as phenols, flavonoids, and anthocyanins were detected in the aqueous, ethanolic, and methanolic extract of $T$. vulgaris (Bellakhdar, 2006 ; Kulišić et al. 2009). Recently, these secondary metabolites are gaining interest as coloring molecules and their dyeing properties. Most of the phenolic compounds include polyphenols such as Apigenin, Luteolin, and Quercitin which are gaining interest in their coloring properties (Guillen \& Manzanos, 1998; Kulišić et al., 2009). According to Kulišić et al. (2009), the aqueous extract contains $33.3 \mu \mathrm{g} / \mathrm{mg}$ EAG, $25 \mu \mathrm{g} / \mathrm{mg}$ flavonoids, and $6.7 \mu \mathrm{g} / \mathrm{mg}$ anthocyanins.

Further, Garcia et al. (2014) succeeded in extracting an Orange hue from the essential oil of T. vulgaris. Similarly, Diaz-Garcia et al. (2015) isolated red color anthocyanin pigment from the flower, and claimed as a food product dyestuff.

To the best of our knowledge, the color spectrum of T. vulgaris remained unexplored. So this study aims to find out the color spectrum of $T$. vulgaris as a natural dye.

\section{Materials and Methods}

To collect information on colorimetric characteristics of dye extracted from $T$. vulgaris, various dyeing trials were carried out under different pretreatment conditions. For this, UV-Visible analysis, colorimetric characteristics, and fastness properties of extracted dye molecules were tested in the current study. This information will help in established a wide spectrum of colors and this could properly define the colorimetric limits of T. vulgaris.

\subsection{Extraction of Dye}

The aerial part of T. vulgaris, which was sourced from ALOUSS cooperative Souss Massa, a region of Morocco, used for dye extraction. The National Office for Sanitary Safety of Food Products (ONSSA) registration number is PAR.27.276. 17. For dye extraction, a solid-liquid dye extraction method was used, for this, dried ground powder of $T$. vulgaris mixed with various solvents i.e. Water, Methanol, and Ethanol in same ratios, after $48 \mathrm{~h}$ of maceration, the extract was obtained by filtration.

\subsection{TLC Chromatography and spectroscopic analysis of the $T$. vulgaris extract}

The presence of a natural dyeing agent of $T$. vulgaris and connected chemicals group was ascertained by TLC Chromatography and UV-Vis analysis. The dried ground powder of T. vulgaris $(5 \mathrm{~g})$ was soaked in $100 \mathrm{ml}$ of water and kept on an ultrasonic (US) water bath for $20 \mathrm{~min}$ at $80^{\circ} \mathrm{C}$. This was followed by the drying of this extraction and again soaked in acetate ethyl for $48 \mathrm{hrs}$. The obtained extract was filtered through ordinary paper and the filtrate was separated with microcrystalline cellulose used as static phase. For the elution, the mobile phase was a solvent mixture of methanol $(65 \mathrm{ml})$, Chloroform $(35 \mathrm{ml})$, and Acetic Acid $(3 \mathrm{ml})$. The fractions were recovered by scraping the 
cellulosic plate and integrated into test tubes. This was followed by the addition of methanol $(\mathrm{MeOH})$ to the plant residues, left for one hour, and filtration with filter paper. The extracts obtained were analyzed using the Double-beam UV-Vis spectrophotometer Perkin Elmer Lambda 2S.

\subsection{Dye properties and spectrum of colors}

The objective of this step was to find out the use of $T$. vulgaris as natural dyes. For this, dye obtained by various extractions (Water, Methanol, and Ethanol) was used for dyeing cotton fabric. For dying, laboratory dyeing machine used is an IR rotary autoclave AHIBA type with IR heating was used at $90^{\circ}$ for $60 \mathrm{~min}$. This machine used for dyeing cellulosic fiber by water-soluble dyes. The bath ratio used for dyeing is $1: 50$ or $2 \mathrm{~g}$ of cotton fabric in $100 \mathrm{~mL}$ of softened water containing dye. For obtaining the significant colorimetric results, Sodium sulfate $\left(\mathrm{Na}_{2} \mathrm{SO}_{4}\right)$ used as an exhausting agent while sodium carbonate $\left(\mathrm{Na}_{2} \mathrm{CO}_{3}\right)$ as a fixing agent and iron sulfate $\left(\mathrm{FeSO}_{4} .7 \mathrm{H}_{2} \mathrm{O}\right)$, Copper (II) sulfate $\left(\mathrm{CuSO}_{4} .5 \mathrm{H}_{2} \mathrm{O}\right)$ and Oxalic acid $\left(\mathrm{C}_{2} \mathrm{H}_{2} \mathrm{O}_{4} .2 \mathrm{H}_{2} \mathrm{O}\right)$ was used as a mordant.

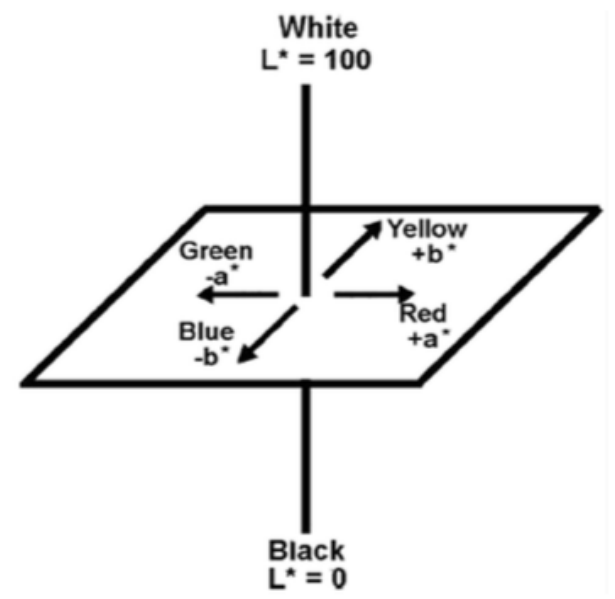

Figure 1 Graphic representation of CIELab color space (Velho et al., 2017)

\subsection{Fabric dyeing properties}

Pure cotton fabric was scoured with $T$. vulgaris dyeing solution containing $2 \mathrm{ml} / \mathrm{L}$ sodium hydroxide, $1 \mathrm{ml} / \mathrm{L}$ non-ionic surfactant (Rucogene), and $1 \mathrm{~g} / \mathrm{L}$ of wetting agent (Rucowet). Fabric with the above-said solutions was boiled for 1 hour at $98^{\circ} \mathrm{C}$. This scoured fabric was bleached with a solution containing $6 \mathrm{~g} / \mathrm{L}$ of hydrogen peroxide, $4 \mathrm{~g} / \mathrm{L}$ stabilizer, $1 \mathrm{~g} / \mathrm{L}$ of a non-ionic surfactant (Rucogene), and $1 \mathrm{~g} / \mathrm{L}$ of wetting agent (Rucowet). The scoured material was rinsed twice and air-dried at room temperature. Further, this scoured material dyed with Sodium sulfate $\left(\mathrm{Na}_{2} \mathrm{SO}_{4}\right)$ and Sodium carbonate $\left(\mathrm{Na}_{2} \mathrm{CO}_{3}\right)$. Before dying, the fabric was mordanted separately with iron sulfate $\left(\mathrm{FeSO}_{4} .7 \mathrm{H}_{2} \mathrm{O}\right)$; Copper (II) sulfate $\left(\mathrm{CuSO}_{4} .5 \mathrm{H}_{2} \mathrm{O}\right)$, and Oxalic acid $\left(\mathrm{C}_{2} \mathrm{H}_{2} \mathrm{O}_{4} \cdot 2 \mathrm{H}_{2} \mathrm{O}\right)$.

\subsection{Color measurements}

Before carrying out any tests, the CIE L*a*b values (CIELAB) were measured using Data color SPECTRAFLACH SF450 (McLaren, 2008). All measurements were calculated under illuminant D65/10 corresponding to daylight with $10^{\circ}$ of observation. As shown in Figure 1 CIELab color system is defined in polar coordinates: $\mathrm{L}^{*}$ from $0^{\circ}$ Black to $100^{\circ}$ White, $\mathrm{a}^{*}$ green to red, and $\mathrm{b}^{*}$ blue to yellow (Velho et al., 2017). The hue (h: $0^{\circ}$ to $360^{\circ}$ ) and chroma (c 0 to 100 ) are also used for the current study. Before each measurement, the data color is first calibrated, operating a standard (dark chamber, white, green), determining the area used (several available diameters). To carry out our colorimetric measurements, DATA COLOR International software is managed for data analysis. To define the CIE LCH coordinates of current study samples, 3 measurements are performed to obtain an average with a standard deviation. This software gives DE value which represents the difference between various measurements according to equation 1 and must be located amidst 0 and 2 .

$D E *=\sqrt{ }(\Delta \mathrm{L} * 2+\Delta \mathrm{C} * 2+\Delta \mathrm{H} * 2)$

\subsection{Colorfastness}

Washing fastness was carried out by using IS-765- 79 method (Jothia, 2008, Vankar et al., 2017). In this, a sample of the dyed material is sandwiched between two adjacent white cotton fabrics and washed together. For this, the bath ratio was 1:50 of marseille soap $(4 \mathrm{~g} / \mathrm{L})$ and hard water. After 20 minutes of soaping at $40^{\circ} \mathrm{C}$, the sample was removed, rinse twice with cold water, pressed it, and air-dried at $60^{\circ} \mathrm{C}$ temperature. Later on, colorfastness value was evaluated using grey scales.

Rubbing fastness was estimated by a crock meter (IS-766-88 Crock meter), in this, transfer of color from the surface of one material to another by either wet or dry rubbing was estimated (Jothia, 2008; Vankar et al., 2017). A friction test with dry and wet trials has redone 20 times. The test is quite sensitive and results are highly changeable, so for getting unchangeable results, it is necessary to use standard crock meter cloth to maintain uniform pressure for applying rubbing strokes and their number. For assessing the degree of color change, a grayscale was used, which represents 1 (bad) to 5 (very good) degrees (Jothia, 2008; Vankar et al., 2017).

\section{Results and Discussion}

\subsection{Extraction and UV analysis}

Dye product obtained by various solvent extractions was used for TLC separation. The solvent system which used as a mobile phase was the combination of methanol, chloroform, and acetic acid in a 
standard ratio $(65 \mathrm{ml}+35 \mathrm{ml}+3 \mathrm{ml}$ respectively). TLC results in 4 color spots i.e. 2 yellow and 2 green (Figure 2). These identified four-color spots marked as extracts 1 to 4 are separated from TLC and subject to chemical analysis by UV-Vis absorption spectroscopy (Figure $3 \& 4$ ). Results of UV-Vis spectra revealed that "Extract 1" and "Extract 2" are logically similar and share a similar spectrum (Figure 3). Further, extract 1 showed 2 UV-vis absorption band spectra, among these Band I was at $\lambda \max 408 \mathrm{~nm}$ and $410 \mathrm{~nm}$ while Band II was at $\lambda \max 270 \mathrm{~nm}$. Previous literature revealed that characterized band spectra are specific for the flavones or flavonols (Kanwal et al., 2016; Kang et al., 2018). Further, according to Kanwal et al. (2016), flavones or flavonols are characterized by two absorption bands in UV spectra: Band I (300- 420) at higher wavelengths is related to $n-\pi^{*}$ transitions and band II $(250-285)$ related to $\pi-\pi^{*}$ chromophoric transitions. Mabry et al. (1970a) elaborated that Band I has associated with absorption due to the B-ring cinnamoyl while Band II absorption involving the A-ring benzoyl system. The results of the current study are in agreement with the findings of Andersen \& Jordheim (2010), those who suggested that flavonoids provide pale yellow colors, which often masked by other pigments. Concerning $\lambda$ max values, it can be concluded that absorption spectra for "Extract 1" and "Extract 2" represent flavonols. To be more specific about the dyeing molecules present in T. vulgaris extract, further analysis

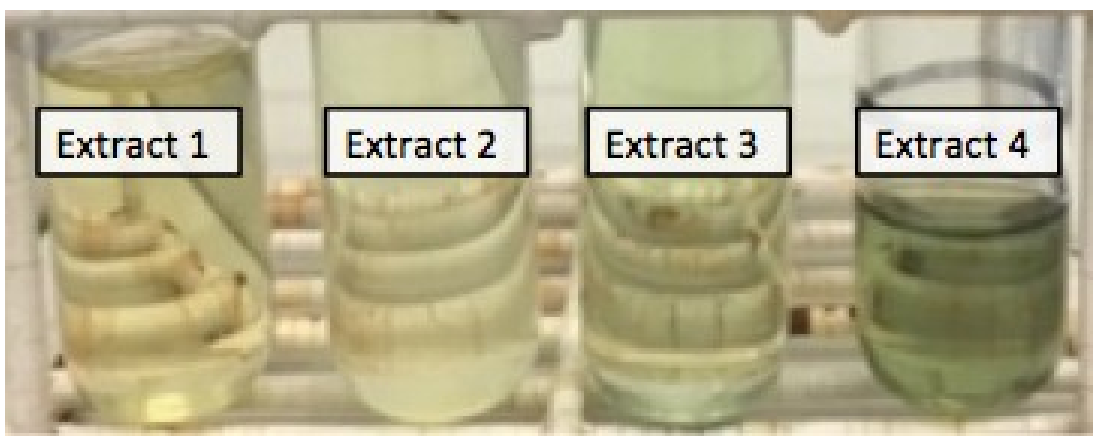

Figure 2 Thin layers chromatography of the methanolic extracts of $T$. vulgaris

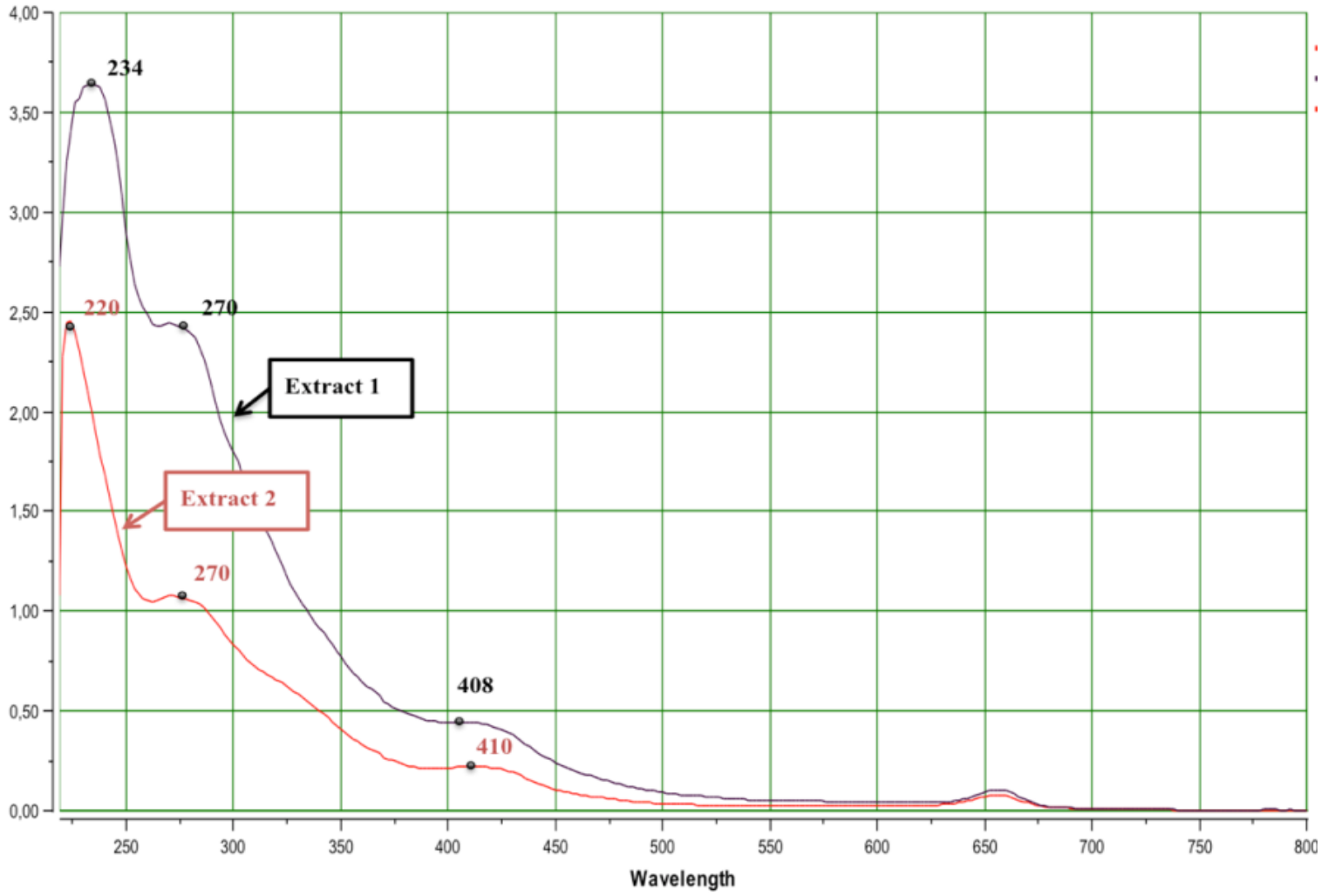

Figure 3 UV-Visible spectrum of Extract 1 and Extract 2 of $T$. vulgaris

Journal of Experimental Biology and Agricultural Sciences http://www.jebas.org 
needs to be carried out. Results of previous studies also suggested that the UV-Vis BAND II value (270nm) is related to Lutein or Apigenin (Kanwal et al., 2016).

In current study BAND I value is a bit higher than the literature data $(360 \mathrm{~nm})$, these differences might be because of the difference in the solvent or instrument used, because these factors might strongly influence the position of the spectra (Mabry et al., 1970b; Schoefs, 2005; Kanwal et al., 2016). On behalf of above-given facts, it can be concluded that extract 1 and 2 are from flavonoids families such as Apigenin or Lutein.

Like extract 1 and 2, in UV-Vis spectra for extract 3 is similar to the UV-Vis spectra extract 4 (Figure 4). For both spectra, Band I is at
$660 \mathrm{~nm}$ in the red region and Band II at 408 and $410 \mathrm{~nm}$ in the blue region. These wavelengths are related to chlorophyll which can easily be recognized by their characteristic green color (Schoefs, 2005; Andersen \& Jordheim, 2010). Indeed, spectra of extract 3 and 4 are similar, and these values are very closely related to the "Pheophytin a" or "Hydroxypheophytin a " which shows band spectra at "667nm and 406 nm" (Diop Ndiaye et al., 2011; Kang et al., 2018). The formation of "Pheophytin a" from chlorophyll is a result of the replacement of $\mathrm{Mg}$ from the Pheophytin ring via acidic substitution and/or heat treatment or after action of $\mathrm{Mg}$ dechelatase (Figure 5). "Pheophytin a" formation is accompanied by color modification from green to olive-brown (Diop Ndiaye et al., 2011; Milenković et al., 2012; Kang et al., 2018).

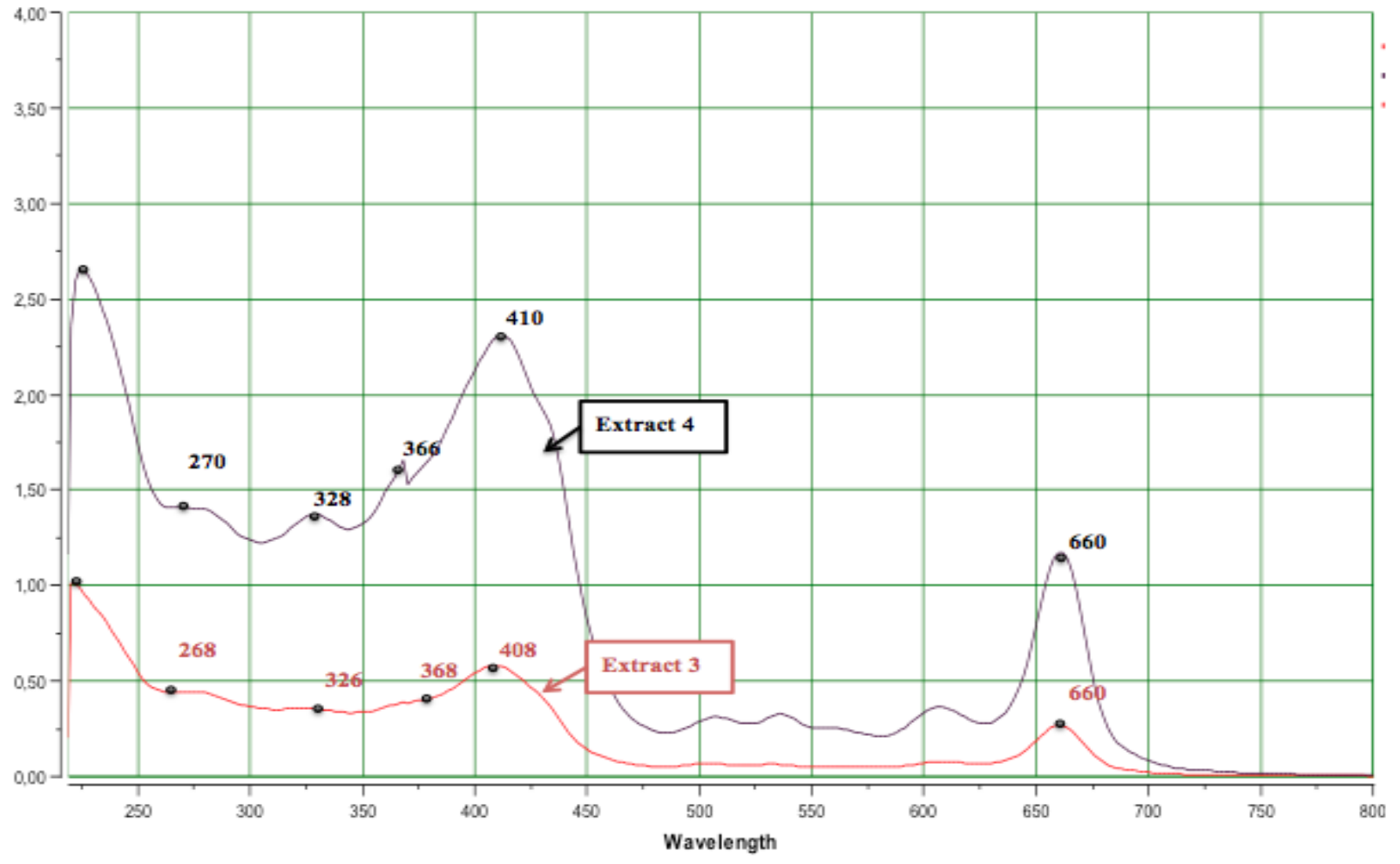

Figure 4 UV-Visible spectrum of Extract 3 and Extract 4 of $T$. vulgaris<smiles>O=c1cc(-c2ccc(O)cc2)oc2cc(O)cc(O)c12</smiles>

A<smiles>O=c1cc(-c2ccc(O)c(O)c2)oc2cc(O)cc(O)c12</smiles>

B

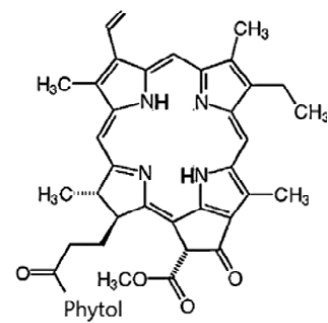

$\mathrm{C}$

Figure 5 Chemical structures of flavones (A: Luteolin;B: Apigenin) (Kanwal et al., 2016) and C: Pheophytins a (Kang et al., 2018)

Journal of Experimental Biology and Agricultural Sciences http://www.jebas.org 


\subsection{Dyeing properties on the cellulosic substrate}

Natural dyes extracted from plants are a combination of several molecules which directly or indirectly involved in the final results. All the reported historical natural dyeing often describes a direct use of powder as a dye. To conserve a uniform experimental approach, we decided to use fine powder of $T$. vulgaris for further trials.

To find out the dyeing behaviors of $T$. vulgaris, a dye extracted with the help of various solvent, was used as a dyeing material. For aqueous extract, the color co-ordinates $\mathrm{L} * \mathrm{CH}$ was 80.414 20.816- 91.854 while this $\mathrm{L}^{*} \mathrm{CH}$ was reported $72.280-20.431$ 90.854 and $72.471-23.875-89.398$ for methanolic and ethanolic extracts respectively. These results revealed that the type of used solvent did not affect the cotton (cellulosic substrate) shades.

For getting better color spectrum, color coordinate, and $\mathrm{DE}^{*}$ values, various salts and metals mordants are used in $0.5 \% \mathrm{w} / \mathrm{w}$ or concerning fabric weight. In addition to the color-coordinate, $\mathrm{DE}^{*}$ also used as a principal rating of the dyeing effect.

The color coordinate and $\mathrm{DE}^{*}$ values of various trials are described in Table 1 . The results of the study suggested that the different trials and mordant give a wide color spectrum from yellow to dark green. Further, the addition of different salts and mordants not only causes differences in the Hue and color co-ordinates but also produces an important change in $\mathrm{DE} *$ or color strength " $\mathrm{K} / \mathrm{S}$ " values which represent the gap between the colors on the color spectrum.

Sample A shown darker Red-yellow color with a $\mathrm{DE} * 15.183$ value from the standard (bare fabric), is the result of only plant powder. Similar results are obtained using salts like Sodium carbonate (B; DE * =18.133) and Sodium Sulfate (F; DE $*=15.367)$. Further, metal mordant Oxalic Acid (E) produces a slight effect on the shade, with a $\mathrm{DE} *=8.264$, while Ferrous sulfate (D) has a color difference with a $\mathrm{DE} *=37.59$. It's the most important result with darker shades that are less red, less yellow. Like the ferrous sulfate, we can relate Copper (II) Sulphate (C) with a value of 26.982. Table 1 represented the $\Delta \mathrm{E}$ (color-changing) values for the 2 months periods; these results are good for all treatments except for Sodium sulfate $\left(\mathrm{Na}_{2} \mathrm{SO}_{4}\right)$. These results suggested that $T$. vulgaris can be used as a natural and organic dye, which provides colors from yellow to somber green. Further, Copper and ferrous mordants are responsible for a drastic change in the Hue. While the oxalic acid shows minor changes in the color coordinate and $\mathrm{DE}^{*}$ values which will be voluntarily dismissed for further trials.

Table 1 CIE Lab Values of cellulosic support dyed with $T$. vulgaris

\begin{tabular}{|c|c|c|c|c|c|c|c|c|}
\hline \multirow{2}{*}{ Sample } & \multirow{2}{*}{ Dyeing with $T$. vulgaris } & \multicolumn{5}{|c|}{ Color Co-ordinates } & \multirow{2}{*}{$\Delta \mathrm{E}$ color } & \multirow{2}{*}{$\Delta \mathrm{E} 2$ month } \\
\hline & & $\mathrm{L}^{*}$ & $a^{*}$ & $b^{*}$ & $\mathrm{C}^{*}$ & $\mathrm{~h}$ & & \\
\hline A & 4g T. vulgaris & 74.47 & 2.25 & 16.42 & 16.57 & 82.20 & 15.182 & 0.856 Good \\
\hline B & $4 \mathrm{~g}$ T. vulgaris $+1 \mathrm{~g} \mathrm{Na}_{2} \mathrm{CO}_{3}$ & 72.92 & 2.47 & 19.14 & 19.30 & 82.64 & 18.133 & 0.766 Good \\
\hline $\mathrm{C}$ & $4 \mathrm{~g}$ T. vulgaris $+1 \mathrm{~g} \mathrm{CuSO}_{4}$ & 62.78 & 1.39 & 20.30 & 20.35 & 86.08 & 26.982 & 0.482 Good \\
\hline $\mathrm{D}$ & $4 \mathrm{~g}$ T. vulgaris $+1 \mathrm{~g} \mathrm{FeSO}_{4}$ & 48.76 & -1.54 & 8.83 & 8.97 & 99.90 & 37.59 & 0.661 Good \\
\hline E & 4g T. vulgaris $+1 \mathrm{~g}$ Ac. Oxalique & 82.08 & 0.09 & 14.19 & 4.19 & 89.63 & 8.264 & 0.628 Good \\
\hline $\mathrm{F}$ & $4 \mathrm{~g}$ T. vulgaris $+1 \mathrm{~g} \mathrm{Na}_{2} \mathrm{SO}_{4}$ & 75.06 & 1.88 & 17.46 & 17.56 & 83.85 & 15.367 & $1.284 \mathrm{Bad}$ \\
\hline
\end{tabular}

Table 2 The total difference in the CIE Lab diagram using T. vulgaris on cellulose with different mordants

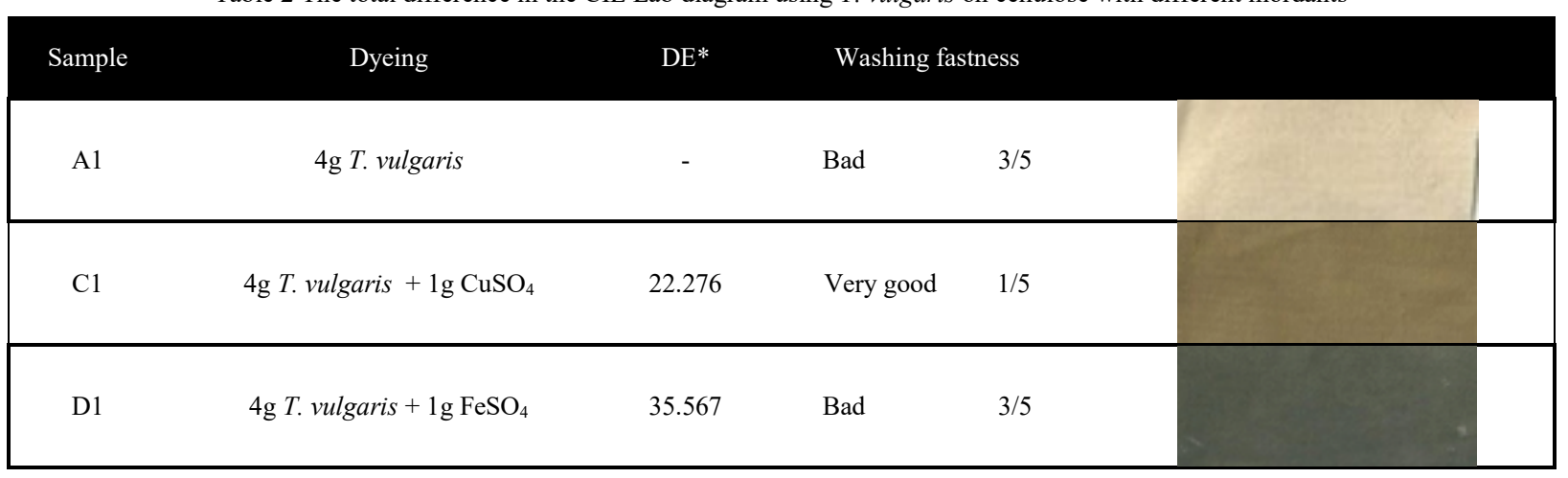


Table 3 CIE Lab Values of cellulosic support dyed with T. vulgaris with different combination of salts and mordants

\begin{tabular}{|ccccccc|}
\hline Samples & Mordant & $\mathrm{Na}_{2} \mathrm{CO}_{3}$ & $\mathrm{Na}_{2} \mathrm{SO}_{4}$ & $\mathrm{~L}^{*}$ & $\mathrm{C}^{*}$ & $\mathrm{~h}$ \\
\hline $\mathrm{A} 1$ (Ref) & & 0 & 0 & 80.42 & 20.82 & 91.86 \\
\hline $\mathrm{A} 2$ & Without & 0.3 & 1 & 70.06 & 26.62 & 86.68 \\
\hline $\mathrm{A} 3$ & Without & 0.7 & 1.5 & 68.37 & 31.14 & 86.21 \\
\hline $\mathrm{C} 1$ (Ref) & $1 \mathrm{~g} \mathrm{CuSO}_{4}$ & 0 & 0 & 59.19 & 26.01 & 81.14 \\
\hline $\mathrm{C} 2$ & $1 \mathrm{~g} \mathrm{CuSO}_{4}$ & 0.3 & 1 & 60.39 & 17.13 & 62.42 \\
\hline $\mathrm{C} 3$ & $1 \mathrm{~g} \mathrm{CuSO}_{4}$ & 0.7 & 1.5 & 38.25 & 21.79 & 52.41 \\
\hline $\mathrm{D} 1(\mathrm{Ref})$ & $1 \mathrm{~g} \mathrm{FeSO}_{4}$ & 0 & 0 & 46.45 & 10.44 & 99.67 \\
\hline $\mathrm{D} 2$ & $1 \mathrm{~g} \mathrm{FeSO}_{4}$ & 0.3 & 1 & 49.26 & 13.03 & 87.86 \\
\hline $\mathrm{D} 3$ & $1 \mathrm{~g} \mathrm{FeSO}_{4}$ & 0.7 & 1.5 & 46.63 & 16.90 & 81.24 \\
\hline
\end{tabular}

\subsection{Impact of the fabric on pre-treatment}

Fabric pre-treatment can make a hue look more vivid especially for the pale shades. To improve the results of current research, a bleached fabric dye of $T$. vulgaris with or without metallic mordant was processed (Table 2). Without any mordant, T. vulgaris provides vivid beige with the following color coordinate (A $1-\mathrm{L}^{*}=80.414$ $\mathrm{C}^{*}=20.816 ; \mathrm{h}^{*}$ 91.845). Copper mordant gives a dark red yellow shade $\left(\mathrm{C} 1 \quad-\mathrm{L}^{*}=59.193 ; \mathrm{C}^{*}=26.009 ; \mathrm{h}^{*}=81.144\right)$. Further, ferrous mordant also produced important color changes and given the deep green shades (D1-L*=46.454; $C^{*=10.444 ; ~} h^{*=99.672) . ~ T a b l e ~} 2$ shows the color $\mathrm{DE}^{*}$ values and washing fastness for every sample. The order of washing fastness with mordant was: Copper mordant $>$ without mordanting $>$ ferrous Mordant. A pre-treated fabric and mordant caused a significant effect on the color changes. These results suggested that mordant can also bring better washing fastness to the fabric like with Copper.

\subsection{Impact of mordant concentration on the fabric shades}

Results of the study already well established that the addition of salts didn't bring any significant change in the fabric color, but after this also these chemicals are used as an exhausting and fixing agent in the textile industry. The concentration of Sodium sulfate and Sodium carbonate for the current study was $0.3 \mathrm{~g} / \mathrm{g}$ and $0.7 \mathrm{~g} / 1.5 \mathrm{~g}$ respectively. Results of mordant concentration on fabric shades revealed that the combination and ratio of mordant imparted suitable to change the shades for all dyeing (Table 3). Using only plant powder dark red shade was observed. The ferrous mordant CIE $\mathrm{L}^{*} \mathrm{c}^{*}$ and $\mathrm{h}$ values showed small changes in color shades. The Copper mordant is the most impacted by the use of combination salts. A substantial gap between the $L^{*}$ and $h$ value which produced shades Kaki, light rose, and brick (Table 3). These results justified the use of $T$. vulgaris as coloring agents for cellulosic subtract.

\subsection{Reproducibility of the natural dye}

The last parameter was to estimate the amount of $T$. vulgaris used for dyeing. Experimental conditions viz., $0.3 \mathrm{~g} \mathrm{Na}_{2} \mathrm{SO}_{4} ; 1 \mathrm{~g}$ $\mathrm{Na}_{2} \mathrm{CO}_{3} ; 100 \mathrm{ml}$ bath volume and $90^{\circ} \mathrm{C}$ for $1 \mathrm{hr}$ autoclave are same for the all trials. The amount of T. vulgaris plant powders used in the current study varied from $1 \mathrm{~g}$ to $4.5 \mathrm{~g}$. Concentrations used in the current study revealed that changes in $\mathrm{K} / \mathrm{S}$ values affect the color shades as shown in figure 6. Lightness in color values decreases with the amount of used plant, which means the samples are getting darker. Hue values start with the 75.56 and reached up to the 86.00 , which represents a negligible gap in a $360^{\circ}$ scale. Further, chroma values are not related to the amount of the used plant and in the current study this gap values were reduced (25 à 28). Non-linear behaviors of a chroma value are usually an indication of a non-reproducible dyeing molecule (Figure 7). Consequently, it can be concluded that the chroma is not impacted and the dye is reproducible for this. 
Table 4 CIE Lab Values of the T. vulgaris Washing and rubbing fastness

\begin{tabular}{|c|c|c|c|c|c|c|c|c|c|c|c|}
\hline No & $\begin{array}{c}T . \\
\text { vulgaris }\end{array}$ & Mordant & $\begin{array}{c}\text { Fixing } \\
\text { agent }\end{array}$ & $\begin{array}{c}\text { Exhausting } \\
\text { agent }\end{array}$ & Sample & $\mathrm{L}^{*}$ & $\mathrm{C}^{*}$ & $\mathrm{~h}$ & $\begin{array}{l}\text { Washing } \\
\text { fastness }\end{array}$ & $\begin{array}{l}\text { Dry rubbing } \\
\text { fastness }\end{array}$ & $\begin{array}{l}\text { Wet rubbing } \\
\text { fastness }\end{array}$ \\
\hline 1 & 2 & 0 & 0.3 & 1 & Good & 71.21 & 24.25 & 80.89 & $\mathrm{Bad}$ & V Good / 5 & V Good / 5 \\
\hline 2 & 2 & 0 & 0.7 & 1.5 & Good & 69.24 & 30.64 & 83.19 & $\mathrm{Bad}$ & V Good / 5 & $\mathrm{Bad} / 3$ \\
\hline 3 & 3 & 0 & 0.3 & 1 & Good & 70.58 & 25.47 & 84.24 & $\mathrm{Bad}$ & V Good / 5 & $\mathrm{Bad} / 3$ \\
\hline 4 & 3 & 0 & 0.7 & 1.5 & Good & 70.15 & 26.90 & 85.09 & $\mathrm{Bad}$ & V Good / 5 & $\mathrm{Bad} / 3$ \\
\hline 5 & 4 & 0 & 0.3 & 1 & Good & 70.06 & 26.62 & 86.68 & $\mathrm{Bad}$ & V Good / 5 & $\mathrm{Bad} / 3$ \\
\hline 6 & 4 & 0 & 0.7 & 1.5 & Good & 68.37 & 31.14 & 86.21 & $\mathrm{Bad}$ & V Good / 5 & $\mathrm{Bad} / 3$ \\
\hline 7 & 2 & $1 \mathrm{gCu}$ & 0.3 & 1 & Good & 66.64 & 13.82 & 66.29 & Good & V Good / 5 & $\mathrm{Bad} / 3$ \\
\hline 8 & 2 & $1 \mathrm{~g} \mathrm{Cu}$ & 0.7 & 1.5 & Good & 52.19 & 21.67 & 55.27 & Good & Good $/ 4$ & $\mathrm{Bad} / 3$ \\
\hline 9 & 3 & $1 \mathrm{~g} \mathrm{Cu}$ & 0.3 & 1 & Good & 57.94 & 17.58 & 59.76 & Good & $\mathrm{Bad} / 2$ & V Bad/ 1 \\
\hline 10 & 3 & $1 \mathrm{gCu}$ & 0.7 & 1.5 & Good & 44.37 & 23.91 & 50.24 & $\mathrm{Bad}$ & Good $/ 4$ & v Bad/1 \\
\hline 11 & 4 & $1 \mathrm{~g} \mathrm{Cu}$ & 0.3 & 1 & Good & 60.39 & 17.13 & 62.42 & Good & Good / 4 & v Bad/1 \\
\hline 12 & 4 & $1 \mathrm{~g} \mathrm{Cu}$ & 0.7 & 1.5 & Good & 38.25 & 21.79 & 52.41 & $\mathrm{Bad}$ & $\mathrm{Bad} / 2$ & v Bad/1 \\
\hline 13 & 2 & $1 \mathrm{~g} \mathrm{Fe}$ & 0.3 & 1 & $\begin{array}{c}\text { Stains / } \\
\text { lacquers }\end{array}$ & 58.17 & 14.41 & 86.36 & $\mathrm{Bad}$ & v Bad/1 & v Bad/1 \\
\hline 14 & 2 & $1 \mathrm{~g} \mathrm{Fe}$ & 0.7 & 1.5 & $\begin{array}{c}\text { Stains / } \\
\text { lacquers }\end{array}$ & 60.98 & 21.62 & 80.80 & $\mathrm{Bad}$ & Color transfer / 0 & Color transfer / 0 \\
\hline 15 & 3 & $1 \mathrm{~g} \mathrm{Fe}$ & 0.3 & 1 & Medium & 46.42 & 12.79 & 85.94 & $\mathrm{Bad}$ & Color transfer / 0 & Color transfer / 0 \\
\hline 16 & 3 & $1 \mathrm{~g} \mathrm{Fe}$ & 0.7 & 1.5 & $\begin{array}{c}\text { Stains / } \\
\text { lacquers }\end{array}$ & 54.42 & 19.12 & 81.56 & $\mathrm{Bad}$ & Color transfer / 0 & Color transfer / 0 \\
\hline 17 & 4 & $1 \mathrm{~g} \mathrm{Fe}$ & 0.3 & 1 & Medium & 49.26 & 13.03 & 87.86 & $\mathrm{Bad}$ & v Bad/1 & v Bad/1 \\
\hline 18 & 4 & $1 \mathrm{~g} \mathrm{Fe}$ & 0.7 & 1.5 & $\begin{array}{c}\text { Stains / } \\
\text { lacquers }\end{array}$ & 46.63 & 16.90 & 81.24 & Good & v Bad/1 & Color transfer / 0 \\
\hline
\end{tabular}
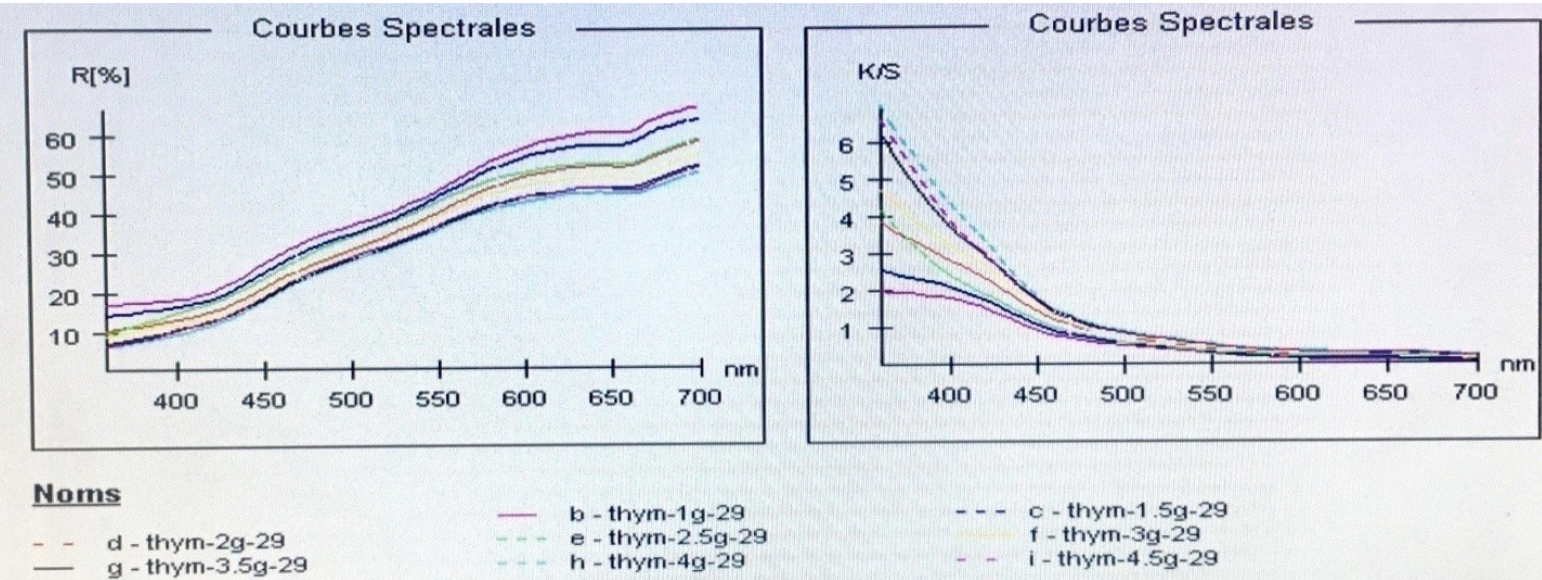

b - thym-1g-29

e - thym-2.5g-29

$\mathrm{h}$ - thym- $4 \mathrm{~g}-29$

- c- thym-1.5g-29

f - thym-3g-29

i - thym-4.5g-29

Figure 6 the spectral reflectance (\%R) and absorption (K/S) graph for the T. vulgaris dyeing

Journal of Experimental Biology and Agricultural Sciences

http://www.jebas.org 


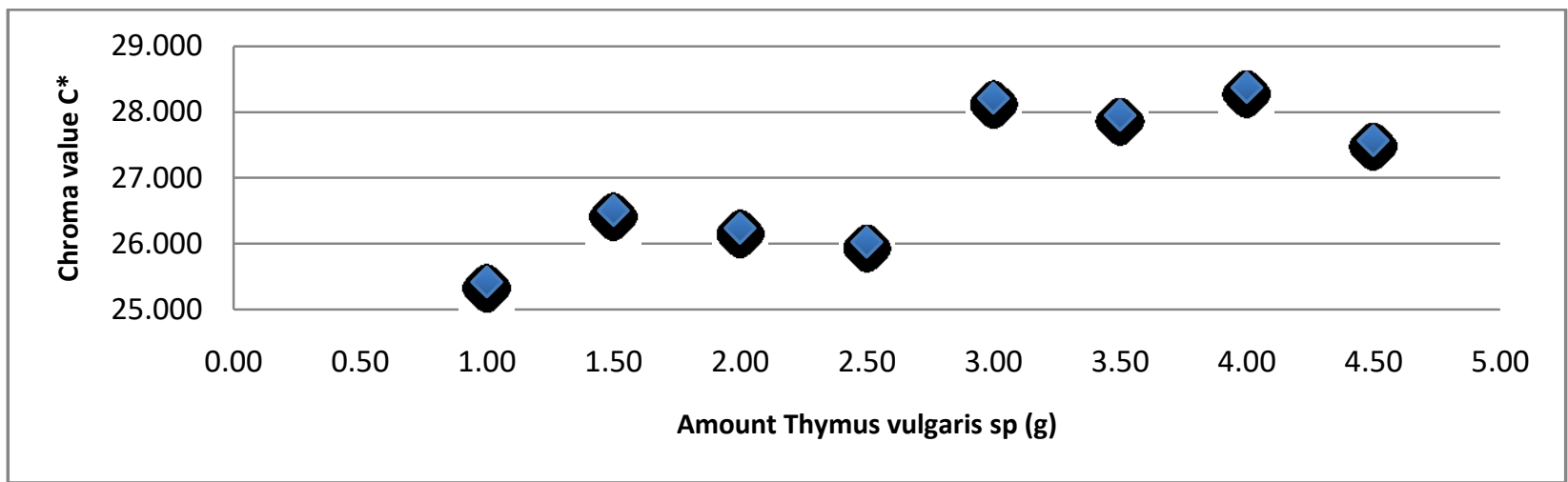

Figure 7 Chroma values of the T. vulgaris $L$ dyeing amount

\subsection{The color spectrum of $T$. vulgaris}

Dyeing conditions affect the color spectrum, in the current study also various concentrations of salts ratio, metallic mordanting, and the amount of the plant powder was used has significant effects on the color spectrum of $T$. vulgaris. Table 4 shows the experimental design and the results of the fastness properties. The amount of the T. vulgaris powder made some changes to the color co-ordinate. While the ratio of pre-treatment salt agents had a significant impact on the shades, it decreases lightness and increases chroma and hue values. Metallic salts used for mordanting dyes changes the color from yellow to reddish-green. It's the most significant condition in the dying process (Table 4).

Washing fastness is not good for almost all the samples but it's increased with the ratio salts. Dry rubbing fastness is substantially good except for the trial using ferrous mordant. Wet rubbing fastness was reported from bad to worse for most of the samples. On average, it can be concluded that the results of the washing and rubbing fastness are weak when the shade is darker.

Many stains were observed in the current study, especially for the ferrous metal which unfixed to the fabric. The results of the washing and rubbing fastness are about 1 to 0 , which revealed a color transfer from the simple to the white specimen (Table 4). In this case, the pigment is also adsorbed by the fiber without fixing. These results revealed that the dye molecule can't fix to the cell because of the non-solvent behaviors. It's especially for the lacquers, which is an insoluble compound of dye molecules and combined to metal salts on their chelating sites by modifying the solubilizing group. It can produce a critical impact on the fastness, especially "rubbing fastness" and opens new perspectives for applications that need insoluble pigment instead of soluble dyes such as cosmetics or paints (Alouani et al., 2016).

\section{Conclusions}

This is the first report where the spectrum colors of $T$. vulgaris is used as a dyestuff for the cellulosic compound. The results of the study suggested that various colors such as yellow, green, or red color can be produced with various lightness and chroma by this plant. Further, the used dyeing conditions are significant and can completely transform the shades especially the ratio of the salt and the metallic mordant used. Washing and rubbing fastness also have an impact on the selected salts and metallic mordant. Ferrous salts give an unusual fastness, but it highlights its behaviors to form lacquers and could be used as pigment for other applications. Further, copper mordant presents good fastness to washing and rubbing, and also produced various shades from green to dark green, and pink to red. Taking everything into consideration, it can be concluded that $T$. vulgaris can be used as a natural dye for the cellulosic compounds and giving various shades. The spectrum could be expended especially through an optimization of the extraction methods. But it's probably not included vivid colors such as bright red or a vivid yellow and green. The $T$. vulgaris spectrum is quite interesting but the saturation is still less efficient than the synthetic dyestuff. Other applications can remain an option for further research, especially for cosmetics and pharmaceutics applications.

\section{Conflict of interest}

Authors would hereby like to declare that there is no conflict of interests that could possibly arise.

\section{References}

Alouani I, Bouyahia Idrissi MO, Draoui M, Bouatia M (2016) Review: From screening to application of moroccan dyeing plants: Chemical groups and botanical distribution. International Journal of Pharmacy and Pharmaceutical Sciences 8(10): 21-31. 
Andersen A, Jordheim M (2010) Chemistry of Flavonoid-Based Colors in Plants. In: Editors: Lewis M; Hung-Wen L (Eds.), Comprehensive Natural Products II: Chemistry and Biology, Elsevier, Oxford Pp. 547-564.

Bellakhdar J (2006) Précis de phytothérapie moderne: plantes medicinalis au Maghreb. Editions le fennec, Casablanca.

Ben Mansour H, Latrach Tlemcani L (2009) Les colorants naturels sont-ils de bons additifs alimentaire? Phytothérapie 7: 202-210.

Cardon D (2014) Le monde des teintures naturelles nouvelle édition. Belin, Paris.

Delgado-Vargas F, Jimenez AR, Paredes-Lopez (2000) Natural pigments: carotenoids, anthocyanins, and betalains- characteristics, biosynthesis, processing and stability. Critical Review in Food Science and Nutrition 40(3): 173-289.

Diaz-Garcia MC, Castellar MR, Obon JM, Obon C, Alcaraz F, Rivera D (2015) Production of an anthocyanin - Rich food colourant from Thymus moroderi and its application in foods Journal of the Science of Food and Agriculture 95(6): 1283-1293.

Diop Ndiaye N, Dhuque-Mayer C, Cisse M, Dornier M (2011) Identification and thermal degradation kinetics of chlorophyll pigments and ascorbic acid from ditax nectar. Journal of Agricultural and Food Chemistry 59(22): 12018-12027.

Garcia M, Saintenoy J, Colomb P (2014) Le Jardin des plantes à couleurs. Verdia, Ville de Namur.

Guillen MD, Manzanos MJ (1998) Study of the different parts of a Spanish Thymus vulgaris L. plant. Food Chemistry 63: 373-383.

Jothia A (2008) Extraction od natural dyes from African Marigold flowers (Tadetes Ereectal) for textile coloration. Autex Research Journal 8(2): 49-53.

Kang YR, Park J, Jung SK, Chang YH (2018) Synthesis, characterization, and functional properties of chlorophylls, Pheophytins and Zn-pheophytins. Food Chemistry 245: 943-950.

Kanwal R, Datt M, Liu X, Gupta S (2016) Dietry flavones as dual inhibitors of DNA methyltransferases and histone methyltranferases. PLOS One 11(9): 1-19.

Křížová H (2015) Natural dyes: their past, present, future and sustainability. In Recent developments in fibrous material Science. OPS, Kanina.

Kulišić T, Kriško A, Dragović-Uzelac V, Miloš M, Pifat G (2009) The effect of essential oils and aqueous tea infusions of oregano (Origanum vulgare L. spp. Hirtum), thyme (Thymus vulgaris L.) and wild thyme (Thymus serpyllum L.) on the copper-induced oxidation of human low-dentisity lipoproteins. International Journal of Food Science and Nutrition 58(2) : 87-93.

Mabry TJ, Markham KR, Thomas MB (1970a) The Ultraviolet Spectra of Flavones and Flavonols. In: The Systematic Identification of Flavonoids. Springer, Berlin, Heidelberg, Pp. 41164. https://doi.org/10.1007/978-3-642-88458-0_5

Mabry TJ, Markham KR, Thomas MB (1970b) The Ultraviolet Spectra of Isoflavones, Flavanones and Dihydroflavonols. In: The Systematic Identification of Flavonoids. Springer, Berlin, Heidelberg, Pp 165-226. https://doi.org/10.1007/978-3-642-88458-0_6

Samanta AK, Agarwal P (2009) Application of natural dyes on textiles. Indian Journal of Fibre \& Textile Research 34: 384-399.

McLAREN K (2008) The Development of the CIE 1976 (L*a*b*) Uniform Colour-Space and Colour-Difference Formula. Journal of the Society of Dyers and Colourists 92:338-341. DOI: 10.1111/j.1478-4408.1976.tb03301.x.

Milenković SM, Zvezdanović JB, Anđelković TD, Marković DZ (2012) The identification of chlorophyll and its derivatives in the pigment mixtures: HPLC-Chromatography, visible and mass spectroscopy studies. Advanced Technologies 1(1): 16-24.

Rababah TM, Banat F, Rababah A, Ereifej K, Yang W (2010) Optimization of extraction conditions of total phenolics, antioxidant activities, and anthocyanin of oregano, thyme, terebinth and pomegranate. Journal of Food Science 75(7): C626-632.

Rajesh Y, Nita Y, Dhar KM (2014) A review: Dye yielding sources and their importance. International Journal of Pharmacy \& Pharmaceutical Research 6(2): 241-248.

Richaud M (2014) Mini guide illustré des plantes médicinales. Hachette Livre.

Samant IA, Gaikwad DK (2020) Optimization of natural dye extraction from coconut husk. Journal of Experimental Biology and Agricultural Sciences 8(1): 54-62.

Schoefs B (2005) Plant pigments: properties, analysis, degradation. Advances in Food and Nutrition Research 49: 41-91.

Shahid M, Shahid-ul I, Faqeer M (2013) Recent advancements in natural dye applications: a review. Journal of Cleaner Production 53: 310-331. DOI: https://doi.org/10.1016/j.jclepro.2013.03.031.

Sivakumar V, Vijaeeswarri J, Lakshmi AJ (2011) Effective natural dye extraction from different plant materials using ultrasound. Industrial Crops and Products 33(1): 116-122. 
Vankar PS (2000) Chemistry of natural dyes. Resonance 5 (10): Velho SRK, Brum LFW, Petter CO, Dos Santos JHZ, Simunic S, 73-80.

Kappa WH (2017) Development of structured natural dyes for use

Vankar PS, Shukla D, Wijayapala S, Samanta K (2017) Innovative silk dyeins using enzyme and Rubia cordifolia extract at room temperature. Pigment \& Resin Technology 46(4): 296-302. into plastics. Dyes and Pigments 136: 248-254.

Viel C (2005) Colorants naturels et teintures du XVIIe siècle à la naissance des colorants de synthèse. Revue d'histoire de la Pharmacie 935347): 327-248. 